\title{
A Importância da Vivencia na Formação Humana do Profissional da Saúde
}

\author{
Schliemann, Ana Laura \\ Universidade de Sorocaba — ana.laura@prof.uniso.br
}

A importância da vivencia na formação humana do profissional da saúde INTRODUÇÃO: Os alunos do curso de saúde da Universidade no primeiro semestre cursam a disciplina de Psicologia Geral. Essa disciplina visa auxiliar o aluno na compreensão do conceito de saúde/doença e suas interfaces com as profissões da saúde e que está inserido nos processos sócio-economicos e políticos da realidade brasileira, além de desenvolver habilidades especificas de comunicação nessa área. Os temas básicos trabalhados são; Conceitos básicos do desenvolvimento humano nos ciclos de vida; Principais teorias em psicologia; grande ênfase na comunicação em saúde e reflexões sobre abordagens profissionais. As estratégias utilizadas são: aulas expositivas, seminários e resolução de casos clínicos pelo método TBL (team basic learning) e preleção dialogada, bem como a utilização de filmes e documentários. Após todo o trabalho realizado na Universidade é realizada uma visitas externa a um asilo de idosos da região. Essa visita é preparada em sala de aula e os alunos devem refletir a realidade e apresentar alternativas de intervenção no meio. OBJETIVO: Desse relato de experiência é refletir sobre a vivência dos alunos dos cursos de saúde: Enfermagem, Nutrição, Farmácia, Terapia Ocupacional e Fisioterapia sobre o contato precoce com idosos em condição asilar. MÉTODO: Após a visita os alunos devem entregar um relatório individual, por escrito, e que responde as seguintes colocações: 1) quais aspectos da visita você considerou mais importante para a sua vida profissional?; 2) como essa visita pode colaborar com a sua vida profissional?; 3) qual o ganho pessoal que você obteve nessa visita?. na próxima aula é feita uma roda de conversa sobre a experiência e como ela pode ser refletida diante da teoria. RESULTADOS: o contato com os idosos favorece o exercício da comunicação adequada a essa fase do desenvolvimento, a percepção das próprias reações e sentimentos, uma reflexão sobre a escolha de uma profissão de saúde e suas vicissitudes. Os alunos escrevem e relatam o quanto essa é a atividade mais importante realizada na disciplina. Quando feita a roda de conversa pode-se observar que os conteúdos teóricos trabalhados são apreendidos e introjetado o conhecimento, há uma apropriação e uma reflexão dos alunos sobre os mesmos. CONCLUSÕES: como preconizam as novas metodologias ativas de aprendizagem, as vivencias praticas quando orientadas pelo docente como atividade de aprendizagem e supervisionadas a posteriori favorecem a compreensão do aluno sobre a realidade da população com a qual irão atuar.

Schliemann, Ana Laura. A Importância da Vivencia na Formação Humana do Profissional da Saúde. In: Anais do Congresso Internacional de Humanidades \& Humanização em Saúde [= Blucher Medical Proceedings, num.2, vol.1]. São Paulo: Editora Blucher, 2014. ISSN 2357-7282

DOI 10.5151/medpro-cihhs-10338 